\title{
SPECTROSCOPIC EVALUATION OF ACTIVATED CHARCOAL AS A POISON ANTIDOTE FOR GLICLAZIDE DRUG
}

\author{
JASIM HAMADI HASSEN ${ }^{1 *}$, ABDALKAREEM HAMAD AYFAN ${ }^{1}$, YASIR MOHAMMED FARHAN ${ }^{2}$ \\ ${ }^{1}$ Department of Pharmaceutical Chemistry, College of Pharmacy, University of Anbar, Ramadi, Iraq. ${ }^{2}$ Department of Clinical Pharmacy, \\ College of Pharmacy, University of Anbar, Ramadi, Iraq. Email: Jasimhu@hotmail.com
}

Received: 11 October 2017, Revised and Accepted: 30 November 2017

\section{ABSTRACT}

Objective: The aim of the present study is to evaluate the ability of activated charcoal in adsorbing overdosage of gliclazide drug, and to study the effects of $\mathrm{pH}$, concentration and time on this process.

Methods: To evaluate the effect of $\mathrm{pH}$, concentration and time; $50 \mathrm{ml}$ of the drug solution (100 mg/L) were allowed to stand with the activated charcoal for $1 \mathrm{~h}$ at $\mathrm{pH}$ of 1.5, 4, 7, and 9 for $\mathrm{pH}$ study. $50 \mathrm{ml}$ of the drug solution concentrations of 25, 50, 75, and 100 (mg/L) were allowed to stand with $1 \mathrm{~g}$ activated charcoal for $1 \mathrm{~h}$ for concentration study. $50 \mathrm{mg}$ of the drug solution (100 mg/L) were allowed to stand with the activated charcoal for $15,30,45$, and 60 min for time study. The concentrations of the adsorbed drug were determined spectrophotometrically.

Results: The adsorption of the gliclazide drug on activated charcoal was found to be $\mathrm{pH}$, concentration, and time-dependent. The amounts of the drug adsorbed were $3,0.75,0.6$, and $0.5 \mathrm{mg} / \mathrm{g}$ for pHs $1.5,4,7$, and 9 , respectively, for $\mathrm{pH}$ study. For concentration study, the amounts adsorbed were 0.15 , $0.22,0.33$, and $0.58 \mathrm{mg} / \mathrm{g}$ for concentrations $25,50,75$, and $100 \mathrm{mg} / \mathrm{L}$, respectively. For time study, the amounts were $0.3,0.4,0.51$, and $0.65 \mathrm{mg} / \mathrm{g}$ for reaction times $15,30,45$, and 60 min, respectively.

Conclusion: The best adsorption circumstances of gliclazide drug on activated charcoal that were found; acidic pH, a high concentration of the drug and longtime of contact.

Keywords: Gliclazide, Activated charcoal, Adsorption, Elimination, Poisoning

(C) 2018 The Authors. Published by Innovare Academic Sciences Pvt Ltd. This is an open access article under the CC BY license (http://creativecommons. org/licenses/by/4. 0/) DOI: http://dx.doi.org/10.22159/ajpcr.2018.v11i3.23054

\section{INTRODUCTION}

Activated charcoal is a fine black odorless and tasteless powder, due to its high adsorptive capacity; it is used as an adsorbent for a large verity of compounds. It is used for removal of colors from solutions [1-3], in the adsorption of gases and vapors such as ammonia, carbon tetrachloride and methane [4], adsorption of nitrogen dioxide from combustion gases [5], and the adsorption of carbon dioxide and methane [6].

Activated charcoal is the most important adsorbent that is able to host many chemical compounds including drugs on its surface in relatively large amounts. This property encouraged scientists in the pharmaceutical field to use it as an antidote for a drug poisoning. It is used for flatulent treatment, and as a good treatment for reducing blood lipid concentrations in patients with uremia and diabetes [7]. It is also used for the adsorption of odors from wounds [8].

An adsorption study of the affinity of two different activated charcoal samples for paracetamol, and the effect of ethanol on the adsorptive properties of the charcoal showed that the use of $10 \%$ ethanol decrease the amount of the drug adsorbed on activated charcoal samples by an amount that might be clinically relevant in cases of intoxications by highgram doses [9]. A $50 \mathrm{mg}$ activated charcoal is able to adsorb $4802.692 \mathrm{mg}$ from tramadol hydrochloride at the gastric condition and $8064.516 \mathrm{mg}$ at the intestinal condition [10]. Activated charcoal has the ability to adsorb a sufficient amount of diazepam drug (200 mg/g-25 mg/g) with maximum adsorption at intestinal $\mathrm{pH}$. The standard dose of $50 \mathrm{~g}$ of activated charcoal was found to be suitable to prevent diazepam intoxication with or without ethanol [11]. Activated charcoal found to be unable to prevent toxicity of some drugs such as acetaminophen, in the gastrointestinal if the administration was beyond $1 \mathrm{~h}$ after a drug overdose. The experiments conducted on fasting volunteers [12]. Super activated charcoal of surface area $2000 \mathrm{~m}^{2} / \mathrm{g}$ was found to be beneficial for eliminating acetaminophen drug $3 \mathrm{~h}$ after overdose ingestion [13]. Increasing activated charcoal dosage and contact time enhance the removal of caffeine, acetaminophen, sulfamethoxazole, sulfamethazine, naproxen, diclofenac, 2, 4-D, triclocarban, and atrazine micropollutants from the water. The adsorption processes varied in dependence on $\mathrm{pH}$ from one drug to another. The decrease in adsorption removal was more significant for hydrophobic than hydrophilic compounds [14]. The adsorption of 2,4-dichlorophenoxyacetic acid (2,4-D) is influenced by the activated charcoal type, adsorbent concentration and solution characteristics. The adsorption process decreases with an increase in $\mathrm{pH}$ over the range 1.5-9. Maximum adsorption occurred at $\mathrm{pH} \approx 2.5$ [15]. The existence of $\mathrm{N}$-acetylcysteine turns down the ability of activated charcoal to adsorb acetaminophen. When salicylic acid was added to simulate a coingestants, $\mathrm{N}$-acetylcysteine significantly decreased salicylate adsorption by activated charcoal [16]. The adsorption capability of activated charcoal measured in mg/g to adsorb 12 different drugs was: Aspirin, 262; glutethimide, 252; methaqualone, 179; chlordiazepoxide, 157; propoxyphene napsylate, 137; diazepam, 136; amitriptyline, 133; propoxyphene hydrochloride, 127; secobarbital, 124; pentobarbital, 103; phenobarbital, 70; and amobarbital, 51. They found that adsorption of the weak acids was most markedly decreased at $\mathrm{pH} 10.8$ [17].

Many factors could affect the adsorption process on activated charcoal such as temperature, pore size, particle, and surface area of charcoal, the solubility of the poison, ionization state of the poison, $\mathrm{pH}$, presence of inorganic salts, and gastric contents [18-20].

Single-dose activated charcoal treatment now becomes the most common method of gastrointestinal decontamination for the poisoned patient $[18,19]$. The method includes oral administration of a single- 
dose activated charcoal or installation by a nasogastric tube of an aqueous mixture of the charcoal after the ingestion of a poison [21]. In general, if the time interval between drug ingestion and activated charcoal administration is increased, the ability of activated charcoal to reduce drug absorption decreases [22].

The aim of this study is to assess the ability of activated charcoal in adsorbing overdosage of gliclazide drug from diabetic patients that may mistakenly ingest overdose from the drug and to study the effects of $\mathrm{pH}$, concentration and time, in order to reach the best conditions for disposal of the drug in case of poisoning.

\section{METHODS}

The activated charcoal used in the present study was obtained from Sigma-Aldrich after repeatedly washed with distilled water; the activated charcoal was dried to constant weight at $105^{\circ} \mathrm{C}$ for over $24 \mathrm{~h}$. All chemicals used in this work were of analytical grade obtained from Sigma-Aldrich. The drug sample of gliclazide was obtained from Servier Company.

The electronic spectra were recorded on PG instruments T80 ultraviolet (UV)/VIS double beam spectrophotometer. The $\mathrm{pH}$ was monitored using a Philips (PW-9409) digital pH meter.

The wavelength at which maximum absorbance occurs $\left(\lambda_{\max }\right)$ was recorded for the aqueous solutions of the drug and found to be $232 \mathrm{~nm}$.

An exact weight of $50 \mathrm{mg}$ of gliclazide was dissolved in $100 \mathrm{ml}$ of methanol in a $500 \mathrm{ml}$ volumetric flask, and the volume was adjusted up to the mark of the flask with distilled water to obtain a stock solution of $100 \mathrm{mg} / \mathrm{L}$. The solution was filtered through Whatman filter paper No. 41.

The flask containing $50 \mathrm{ml}$ of gliclazide solution (100 mg/L) and $1 \mathrm{~g}$ of activated charcoal was shaken at room temperature for $1 \mathrm{~h}$ and $\mathrm{pH}$ of $1.5,4,7$, and 9 for $\mathrm{pH}$ dependence study. For the concentration dependence study, $50 \mathrm{ml}$ of the drug solution of concentrations 25 , 50,75 , and $100 \mathrm{mg} / \mathrm{L}$ were shaken with $1 \mathrm{~g}$ activated charcoal for $1 \mathrm{~h}$. For time dependence study, $50 \mathrm{ml}$ of drug solution (100 mg/L) were shaken with $1 \mathrm{~g}$ activated charcoal for $15,30,45$, and $60 \mathrm{~min}$. The mixtures were shaken vigorously at room temperature using magnetic stirrer after which filtered through filter paper, and the filtrate assayed spectrophotometrically in the ultraviolet region at $\lambda=232$ for residual drug concentration. The process was repeated under different equilibrium conditions of $\mathrm{pH}$, concentration, and time. The $\mathrm{pH}$ was adjusted using $0.1 \mathrm{~N}$ solution of $\mathrm{HCl}$ and $\mathrm{NaOH}$.

The amount of the drug adsorbed was calculated spectrophotometrically using the equation:

$Q_{e}=\left(C_{0}-C_{e}\right) V / m$

Where $Q_{e}$ is the maximum quantity of the drug in $\mathrm{mg} / \mathrm{g}$ adsorbed on the activated charcoal, $\mathrm{C}_{0}$ is the initial concentration $(\mathrm{mg} / \mathrm{L})$ of the drug solution, $\mathrm{C}_{\mathrm{e}}$ is the concentration of the drug $(\mathrm{mg} / \mathrm{L})$ in the supernatant at the equilibrium stage, $\mathrm{V}$ is the volume of the drug solution in liter, and $\mathrm{m}$ is the mass of adsorbent employed in grams.

The calibration curve was accomplished by measuring the absorbance of solutions for each experiment, thereafter plotting of absorbance versus $\mathrm{PH}$, concentrations, and time.

\section{RESULTS AND DISCUSSIONS}

Gliclazide belongs to the sulfonylurea class; it is an anti-diabetic medication used to treat diabetes mellitus. It is a white crystalline powder, relatively insoluble in water, sold under the brand name Diamicron. The chemical formula is $\mathrm{C}_{15} \mathrm{H}_{21} \mathrm{~N}_{3} \mathrm{O}_{3} \mathrm{~S}$, and the chemical name is [1-(3-azabicyclo $(3,3,0)$ oct- 3-yl)-3-p-tolylsulfonylurea] [23]. The chemical structure of the drug is shown in Fig. 1.
The drug exhibits slow gastrointestinal absorption rate and interindividual variations of its bioavailability. Oral bioavailability of the drug is in the range of $79-81 \%$. The half-life of the drug is about $10 \mathrm{~h}$. The UV spectrum of the gliclazide solution is shown in Fig. 2.

The results of $\mathrm{pH}$ dependence study are presented in Table 1. The amount of the drug adsorbed increasing with decreasing $\mathrm{pH}$. The $\mathrm{mg} / \mathrm{g}$ values seem to be small. At pH 4, 7 and 9 the values are almost identical, but a noticeable jump is clear at $\mathrm{pH} 1.5$.

Fig. 3 shows a plot of absorbance versus $\mathrm{pH}$. The jump in the amount of the drug adsorbed at $\mathrm{pH} 1.5$ is very clear.

An increase in adsorption was observed with an increase in the concentration of the drug as shown in Table 2. The maximum adsorption was attained at $100 \mathrm{mg} / \mathrm{L}$. Here again, the amounts of gliclazide drug adsorbed are small.

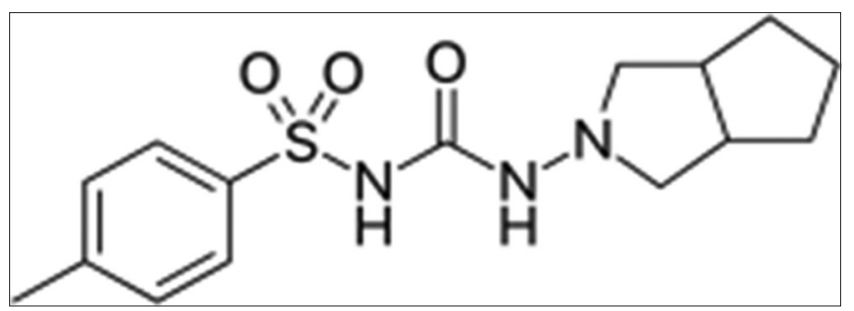

Fig. 1: The chemical structure of gliclazide

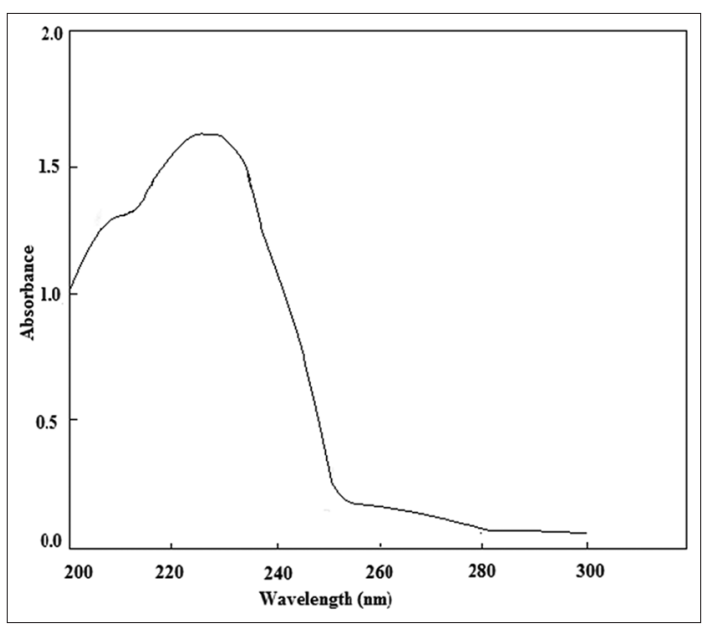

Fig. 2: The ultraviolet spectrum of gliclazide

Table 1: Parameters of $\mathrm{pH}$ dependence study

\begin{tabular}{lll}
\hline $\mathbf{p H}$ & $\begin{array}{l}\text { Concentration of adsorbate } \\
\mathbf{m g} / \mathbf{L}\end{array}$ & Gliclazide adsorbed $\mathbf{~ m g} / \mathbf{g}$ \\
& 40 & 3 \\
\hline 1.5 & 85 & 0.75 \\
7 & 88 & 0.6 \\
9 & 90 & 0.5 \\
\hline
\end{tabular}

Table 2: Parameters of concentration dependence study

\begin{tabular}{lll}
\hline Concentration $\mathbf{~ m g / L}$ & $\begin{array}{l}\text { Concentration of } \\
\text { adsorbate } \mathbf{~ m g / L}\end{array}$ & $\begin{array}{l}\text { Gliclazide adsorbed } \\
\mathbf{~ m g / g}\end{array}$ \\
\hline 25 & 22 & 0.15 \\
50 & 45.5 & 0.22 \\
75 & 68.5 & 0.33 \\
100 & 8.58 & 0.58 \\
\hline
\end{tabular}


Table 3: Parameters of time dependence study

\begin{tabular}{lll}
\hline Time (min.) & $\begin{array}{l}\text { Concentration of } \\
\text { adsorbate } \mathbf{~ m g / L}\end{array}$ & Gliclazide adsorbed $\mathbf{~ m g / g}$ \\
\hline 15 & 94 & 0.3 \\
30 & 92 & 0.4 \\
45 & 89.8 & 0.51 \\
60 & 87 & 0.65 \\
\hline
\end{tabular}

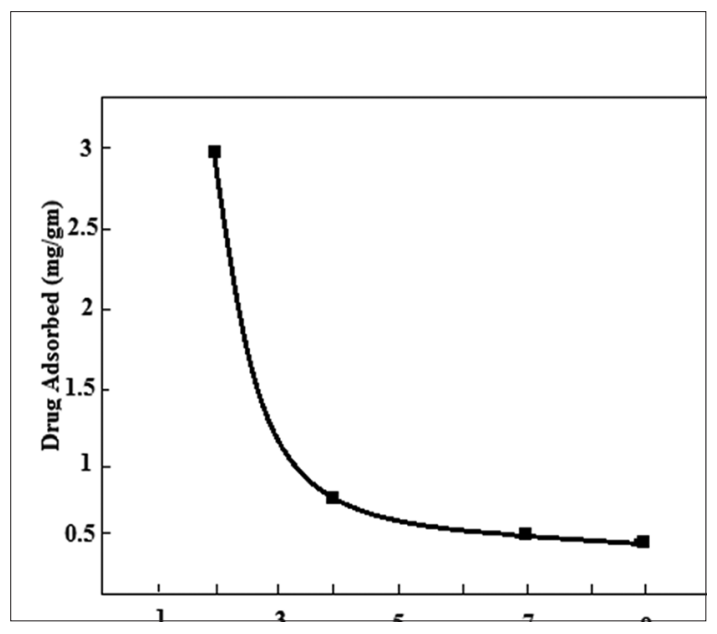

Fig 3: Plot of adsorbed drug (mg/g) versus $\mathrm{pH}$ for $\mathrm{pH}$ dependence study

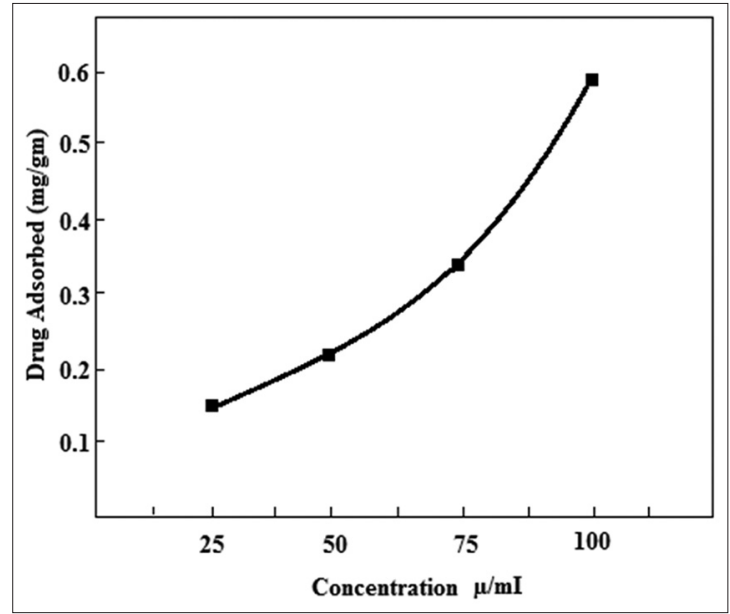

Fig. 4: Plot of adsorbed drug (mg/g) versus concentration for concentration dependence study

Fig. 4 is a plot of absorbance versus concentration for concentration dependence study.

Table 3 summarizes the parameters for time dependence study. It was found that the adsorption of the drug increases at the time of reaction increases. The relation between the time of reaction and absorbance is shown in Fig. 5.

It is obvious from the parameters in Tables 1-3 that the amounts of the gliclazide drug sample adsorbed on activated charcoal are low in all the experiment factors used ( $\mathrm{pH}$, concentration and time). That might be due to the poor solubility of the drug in water. Water is the only solution that has preferred ability to penetrate the pore structure of activated charcoal and many other adsorbents including clays. The bioavailability of a drug is an important factor that is connected with solubility. For any

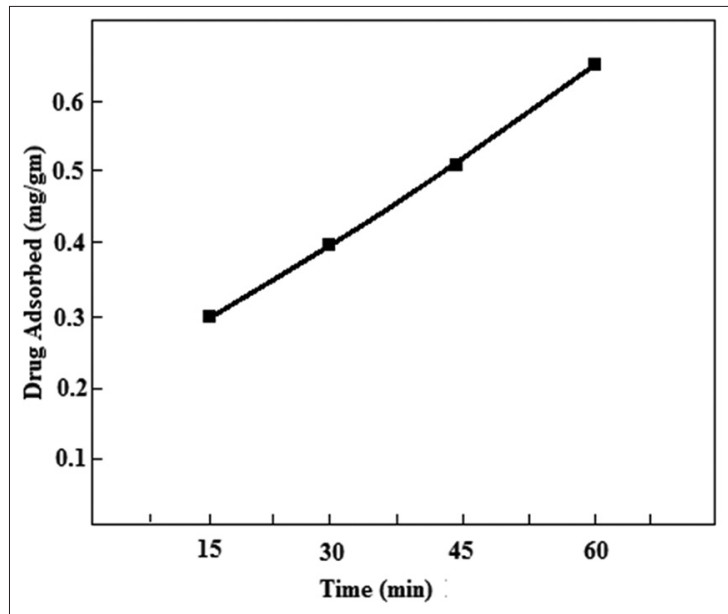

Fig. 5: Plot of adsorbed drug (mg/g) versus time for time dependence

drug to be absorbed in the gastrointestinal tract it must be dissolute first.

The enhancement of the solubility of insoluble or poorly soluble drugs in the water now become a major challenge for researchers [24]. Different techniques have been developed for this purpose, of which is the low-surfactant microemulsion gels [25], Liquisolid technique [26], and micronization through $\mathrm{pH}$ change [27].

The amounts of the gliclazide taken by the surface of activated charcoal increase with increase the time of contact and concentration of the drug and decrease the $\mathrm{pH}$.

From the three factors studied it is of interest to note that the biggest amount of the drug adsorbed was $3 \mathrm{mg} / \mathrm{g}$ found at low $\mathrm{pH}$ (1.5). Although this amount is also small compared to the amounts of drugs adsorbed on activated charcoal that is mentioned in the literature, nevertheless it remains a good result. The $1.5 \mathrm{pH}$ is similar to the $\mathrm{pH}$ of the gastric fluid which makes activated charcoal a good antidote for gliclazide poisoning since the gastric fluid is also acidic which enhance the elimination of the drug through adsorption on activated charcoal and help in gastrointestinal decontamination.

Multiple-dosage of activated charcoal in acidic pH can be suitable for elimination the gliclazide drug from the human body. Since the quantities adsorbed is small, the repeated dose is recommended.

\section{CONCLUSIONS}

The adsorption of gliclazide drug on activated charcoal found to be very low at different $\mathrm{pH}$, concentrations, and time. That might be due to the poor solubility of the drug in water. Water has preferred ability to penetrate the pore structure of activated charcoal. The greatest amount adsorbed was found at $1.5 \mathrm{pH}$ which makes activated charcoal antidote of choice for elimination gliclazide drug since the $\mathrm{pH}$ of the gastric fluid is similar to this value. An increase in adsorption was observed with an increase in the drug solution concentration and contact time. An increase in the adsorption was also observed with decreasing the $\mathrm{pH}$ of the gliclazide drug solutions.

\section{ACKNOWLEDGMENTS}

Authors acknowledge the Department of Pharmaceutical Chemistry and the Department of Clinical Pharmacy, College of Pharmacy, University of Anbar, Iraq, for providing facilities to carry out this research. 


\section{CONFLICT OF INTEREST}

The authors do not have any conflict of interest.

\section{AUTHORS CONTRIBUTIONS}

The idea of the research was suggested by Dr. Jasim H. Hassen, along with literature collection, manuscript writing, editing and data calculations. The materials preparation and laboratory experiments work were carried out by Abdalkareem H. Ayfan and Yasir M. Farhan with the participation of Dr. Jasim H. Hassen. Manuscript revision was done by Yasir M. Farhan.

\section{REFERENCES}

1. Bangash FK, Manaf A. Kinetics of removal of dye (Basic Blue 3) from aqueous solution by activated charcoal prepared from the wood of Brausonitia Papyrifera (paper mulberry). J Chem Soc Pak 2004;26:111-5.

2. Bangash FK, Manaf A. Dyes removal from aqueous solution using wood activated charcoal of Bombax Cieba tree. J Chin Chem Soc 2005;52:489-94.

3. Hassen $\mathrm{JH}$, Effect of $\mathrm{KOH}$ ratio on the formation of activated carbon from pressed wood residues. Int J Pharm Sci Res 2017;8:4875-80.

4. Khan G, Uddin F, Khan MN, Tahir H. Manometrical studies on the adsorption of some organic gases/vapors on the surface of activated charcoal. Arab J Sci Eng 2003;28:35-41.

5. Rubel AM, Stencel JM, Ahmed SN. Activated carbon for control of nitrogen oxide emissions. J Mater Res 1995;10:562-7.

6. Goetz V, Pupier O, Guillot A. Carbon dioxide-methane mixture adsorption on activated carbon. Adsorption 2006;12:55-63.

7. Lapus RM. Activated charcoal for pediatric poisonings: The universal antidote? Curr Opin Pediatr 2007;19:216-22

8. Shreve RN, Brink JA Jr. Chemical Process Industries. $4^{\text {th }}$ ed. Toronto: McGraw-Hill Books; 1976.

9. Hoegberg LC, Angelo HR, Christophersen AB, Christensen HR. Effect of ethanol and $\mathrm{pH}$ on the adsorption of acetaminophen (paracetamol) to high surface activated charcoal, in vitro studies. J Toxicol Clin Toxic 2002;40:59-67.

10. Pandeya S, Gharti KP, Bharati L, Pandey A. In-vitro kinetics, adsorption isotherm, and effect of $\mathrm{pH}$ on antidotal effect of activated charcoal in tramadol hydrochloride intoxication. Int J Pharm Sci Res 2016;7:63-71.

11. Sah SK, Joshi D, Pathak S, Regmi S, Regmi BM, Manandhar PN, et al. Effect of ethanol and $\mathrm{pH}$ on the in vitro adsorption of diazepam onto activated charcoal from simulated gastric fluid and simulated intestinal fluid. Indian J Pharm Sci 2016;78:624-30.

12. Green R, Grierson R, Sitar DS, Tenenbein M. How long after drug ingestion is activated charcoal still effective? J Toxicol Clin Toxicol 2001;39:601-5.

13. Sato RL, Wong JJ, Sumida SM, Marn RY, Enoki NR, Yamamoto LG, et al. Efficacy of superactivated charcoal administered late (3 hours) after acetaminophen overdose. Am J Emerg Med 2003;21:189-91.

14. Nam SW, Choi DJ, Kim SK, Her N, Zoh KD. Adsorption characteristics of selected hydrophilic and hydrophobic micropollutants in water using activated carbon. J Hazard Mater 2014;270:144-52.

15. Belmouden M, Assabbane A, Ichou YA. Adsorption characteristics of a phenoxy acetic acid herbicide on activated carbon. J Environ Monitor 2000;2:257-60.

16. Tenenbein PK, Sitar DS, Tenenbein M. Interaction between $\mathrm{N}$-acetylcysteine and activated charcoal: Implications for the treatment of acetaminophen poisoning. Pharmacotherapy 2001;21:1331-6.

17. Sellers EM, Khouw V, Dolman L. Comparative drug adsorption by activated charcoal. J Pharm Sci 1977;66:1640-1.

18. Cooney DO. Activated Charcoal in Medical Applications. $2^{\text {nd }}$ ed. New York, NY: Marcel Dekker; 1995.

19. Watson WA, Litovitz TL, Klein-Schwartz W, Rodgers GC Jr., Youniss J, Reid N, et al. 2003 Annual report of the American association of poison control centers toxic exposure surveillance system. Am J Emerg Med 2004;22:335-404.

20. Baccar R, Sarra M, Bouzid J, Feki M, Blanquez P. Removal of pharmaceutical compounds by activated carbon prepared from agricultural by-product. Chem Eng J 2012;211:310-7.

21. Chyka PA, Seger D, Krenzelok EP, Vale JA, American Academy of Clinical Toxicology, European Association of Poisons Centres and Clinical Toxicologists, et al. Position paper: Single-dose activated charcoal. Clin Toxicol (Phila) 2005;43:61-87

22. Yeates PJ, Thomas SH. Effectiveness of delayed activated charcoal administration in simulated paracetamol (acetaminophen) overdose. $\mathrm{Br}$ J Clin Pharmacol 2000;49:11-4.

23. More CG, Dabhade PS, Jain NP, Aher BO. Solubility and dissolution enhancement of gliclazide by solid dispersion technique. Int J Pharm Chem Ana 2015;2:51-8.

24. Vimalson DC, Parimalakrishnan S, Jeganathan NS, Anbazhagan S. Techniques to enhance the solubility of hydrophobic drugs: An overview. Asian J Pharm Sci 2016;10:67-75.

25. Shalviri A, Sharma A, Patel DD, Sayani A. Low-Surfactant microemulsions for enhanced topical delivery of poorly soluble drugs. J Pharm Pharm Sci 2011;4:315-24.

26. Panda S, Varaprasad R, Priyanka K, Swain RP. Liquisolid technique: A novel approach for dosage form design. Int J Appl Pharm 2017;9:8-14.

27. Talari R, Varshosaz J, Mostafavi SA Nokhodchi A Dissolution enhancement of gliclazide using $\mathrm{pH}$ change approach in presence of twelve stabilizers with various physico-chemical properties. J Pharm Pharm Sci 2009;12:250-65. 